\title{
Supporting And Developing Self-Regulatory Behaviours In Early Childhood In Young Children With High Levels Of Impulsive Behaviour
}

\author{
Dr. Aviva Dan, Ohalo College, Israel
}

\begin{abstract}
Deficits in self-regulatory skills underlie or contribute to a range of adverse developmental problems and disorders, including ADHD (Barkley, 1997), eating disorders (Attie \& Brooks-Gunn, 1995) and risk-taking behaviour (Cantor \& Sanderson 1998; Eisenberg et al., 2005). Self-regulation has been recognised as an important factor in aiding academic achievements of school-age children. There is less knowledge of the subject in early childhood, yet the development of self-regulatory has been described as an important milestone in early childhood development (Shonkoff \& Phillips, 2000). This research describes the implementation of an intervention programme in kindergartens that aimed to help young children with highly impulsive behaviour, develop self-regulatory behaviors. The children were identified by the Achenbach Child behaviour check list (1.5-5) and by the kindergarten teachers. This Research was based on mixed methods. The quantitave data reveled a number of child ren with highly impulsive behaviour and difficulties in self-regulation. The qualitative data gave a deeper interpretation to these children's behaviourand the difficulties involved. After the implementation of the program the kindergarten teachers reported on an increase in the children's self-regulatory skills.
\end{abstract}

By understanding and supporting the processes involved in the development of self-regulation skills, it might be possible for significant adults in young children's lives to have a substantial effect in aiding young children, who are highly impulsive. This was the rationale for the present research.

Keywor ds: Self-Regulatory; Early Childhood; Impulsive Behaviour

\section{INTRODUCTION}

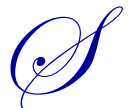

elf-regulation consists of an array of complex mental capacities that include impulse and emotional control, self- guidance of thought and behaviour planning, self-reliance and socially responsible behaviour (Bronson, 2000; Kopp, 1991). According to the psychoanalytical theory of Freud (1936) humans are born with basic drives; the 'id' which is the base of psychic energy, the 'ego' which has executive control and the 'superego' which mediates between the individual's drives and the moral demands of society. Erikson (1950), in comparison, perceived the 'ego' as an autonomous structure that strives to meet its needs and adapt to the environment This successfulability to adapt to the environment is the result of an individual being able to regulate personal desires in accordance to society's demands. In contrast to the psychoanalytical school of thought, behavioural theorists like Skinner (1938) conceive self-regulation as learned self-control. There is no internal control of desires or personal drives, self-control is learned behaviour that attains positive feedback from the environment and is therefore behaviour that it is advantageous to adopt. This perception of the acquisition of self-control is very simplified and depends on an external 'locus'of control. The individual has less responsibility for their behaviour.

Albert Bandura (1977, 1997) perceived learning as occurring through observation without any need for external reinforcement; the individual learns by observation and evaluation which behaviours are valued by society and which are not. These evaluations lead to an understanding of probable outcomes for certain behaviours and the building of internal criteria that regulate personal behaviour. With the increase of internal criteria for behaviour, the individual is 
less dependent on external rewards or negative reactions. Thus, the development of self-regulation is an internal differentiated graduated process, dependent on the interaction between the individual's observation and society. For a child to successfully take part in society, he needs to have a combination of internal natural abilities and also needs the assistance of significant adults in their life who should provide efficient mediation and reflection to the child about their behaviour.

Like Bandura, Vygotsky (1962) saw the development of self-control as an integrative process between the individual and society. According to his perception, the desire for self-control is innate, and the socio-cultural environment plays an important role in the outset of self-regulatory behaviours. Vygotsky believed that the interactions that assist in the development of self-regulating behaviour involved active 'scaffolding' by significant adults or peers. The act of 'scaffolding' involved modelling strategies, questions and other supporting behaviour that allow the child to build independent self-regulated behaviour. This support has to occur in the 'Zone of Proximal Development' (ZPD), a virtual area that exists between a child's present abilities and what a child can achieve with support; this area represents the child's ability to learn (Vygotsky, 1962).

Vygotsky asserted that language was the main cultural tool for enhancement of self-regulatory behaviours, language being the prime means of thought and voluntary self-regulation. The development of language occurs in stages, the first stage consists of developing language skills for communication and self-expression, at a later stage language becomes an internalised tool for regulating thoughts and actions. Vygotsky and Piaget observed Egocentric or 'private' speech in young children. Private speech is an on-going monologue that accompanies activities, at a later stage; it precedes or assists activities and by the age of six years it becomes internalised and part of internal thought processes and behaviour regulation. Vygotsky was also aware of the effect of culture on the development of higher levels of thought and self-regulatory behaviour. Each culture has a specific language, ways of solving problems and views on self- regulatory appropriate behaviour (Bronson, 2000). Vygotskian theory acknowledges the basic desire of individuals to take part in community life and be part of society. For this desire to be fulfilled the individual needs to be able to mediate between external and internal processes. According to Vygotsky, this is a social and cognitive development process that occurs in stages and the environment can assist in guidance or 'scaffolding' (Vygotsky, 1986).

In contrast, to Vygotsky, Piaget (1985) believed that human development occurs as a result of two complementary processes, 'accommodation' and 'adaptation'. The young child actively interacts with the physical environment and as such receives information through sensory channels. If the information received is inconsistent with present existing information, then the experience causes a state of mental disequilibrium. If the incoming information is similar to existing mental structures, then there is a state of equilibrium. In a state of disequilibrium, a natural mechanism of accommodation will occur to adapt and change the existing 'schemes' (Ibid.). Piaget's universal theory indicates that development occurs in stages according to natural growth. The direction of development is towards increasingly stable mental structures and processes that are adaptive to reality. Decisions and behaviour are governed by cognitive capacities and self-regulatory behaviour increases as a result of cognitive development. Self- regulating behaviour develops out of a combination of personal experiences, observations and processes of adaptation to reach the ideal state of equilibrium with society. Piaget's theory does not address the interactive relationship between individual and society or the emotional factors involved in such a process.

Each of the various psychological theories has addressed the development of self-regulating behaviour from their particular perspective. The ability to control actions and behaviour are of utmost importance to enable an individual to integrate successfully into society. The motivation to want to take control of one's actions and behaviour is affected by biological factors such as temperament, the maturity of certain brain structures and environmental factors, such as culture.

\section{Development of Self-Regulation at an Early Age}

Rothbart and others define self-regulation as the child's ability to modulate behaviour according to the cognitive, emotional, and social demands of a particular situation (Posner \& Rothbart, 2000). The immediate responses of the infant are a result of reactions to sensory stimuli of different qualities and intensities. This reactivity is thought to be present from birth and reflects a relatively stable characteristic of the infant (Rothbart, Derryberry \& Hershey, 2000 ). Regulatory processes begin to develop prenatally and evolve into more sophisticated and self-initiated processes over 
the course of development from toddler to preschool and into school age (Posner \& Rothbart, 2000; Rothbart \& Jones, 1998).

\section{Self- Regulation and Maturity of Brain Structures}

Research on brain activity has increased dramatically, the knowledge shows that certain areas of the brain structure that are responsible for self-regulatory abilities. The frontal lobes of the brain support a variety of self-regulatory or executive functions which include the ability to inhibit the behavioural response, control distractions, regulate emotions, hold and analyse information in working memory, generate and manage internal motivation, plan and sequence activities (Bronson, 2000).

Research shows qualitative differences between younger and older children in their capacity to engage in more organised and effective cognitive processing as they grow older. Younger children possess fewer 'executive control structures', which are responsible for attention spans and self-regulatory behaviours (Case, 1992). With the increase in age the process becomes more sophisticated as the brain matures, and by the age of six or s even, children begin to develop meta-cognitive skills that allow them to understand and monitor their cognitive processes (Brown, 1978; Brown \& De Loache, 1978; Flavell, 1978). Children of this age gain better control of attention and memory. They learn to use feedback and actively attempt to modify their behaviour, although according to Kopp (1982), the ability to develop self-regulatory functions is present from birth.

Kopp (1982) describes the developmental process from control of arousal and sensory fu nctions in the early months of life to an increased ability to comply with external demands at the end of the first year and then the beginning of the ability to control internal impulses in the second year(Kopp, 1982). Self-regulating is present from the early stages, in the first few months of life.At this stage, the neurophysiological systems help protect the newly born child from extensive stimuli.

Babies can minimise the extent of arousal by turning their gaze away or shutting their eyes when they feel overaroused, or by engaging in self-calming methods such as sucking on a pacifier. When a young baby is able to differentiate between day and night in their sleeping patterns and enter into a regular feeding schedule, they enter the next stage. Small babies can use other strategies of self-regulation such as diverting attention. Johns on and Rothbart (1991) described the behaviour of infants, 3-6 months old, who were distres sed because of exces sive auditory or visual stimuli. These young infants learned to divert their attention to alternative stimuli that were less excessive, and as such reduce the symptoms of stress. By the age of 9-12 months, a young baby can consciously engage in actions that are focused on specific targets, like reaching out to place a pacifier in its mouth to self-regulate.

By the end of the first year, babies can act on simple orders (Kopp, 1982). During the second year, toddlers develop their ability to feel more complicated feelings, such as pride and shame, which are signs of s elf-awareness (Sroufe, 1996; Lewis, Alessandri \& Sullivan, 1992). More advanced motor and cognitive abilities enable them to control their behaviour and allow them to be receptive to outside demands for self-control. There is still difficulty in delaying selfgratification and in initiating self-regulation strategies, and in times of stress or emotional arousal, the young toddler will exhibit frustration by crying or throwing themselves on the floor in anger, screaming and kicking. By kindergarten age, 3-6 years, there is an increased ability in cognitive strategies, such as language, to control impulses and emotions, and more awareness of social standards. Children of this age group can also monitor their behaviour according to external demands (Flavell, Miller \& Miller, 2002).

As already noted, the concept of 'mutual regulation' refers to the ability of each partner to recognise and understand the emotional and affective expressions and signals of the other and to support the interaction in a way that will effectively allow the interactions to continue. The characteristics of each partner in this dialogue will influence the quality of the interpersonal interactions; this is also true of the partners' temperamental traits. Following the classical longitudinal studies on the subject of 'temperament' by Thomas, Chess and Birch (1968) temperament has been assessed and studied in a variety of ways. The assumption being temperamental traits, which are genetically based, determine the characteristic patterns of responding to the environment and also help to regulate inner sensations and the formation of patterns of interpers onal relationships (Klien \& Yablon, 2008). Temperamental characteristics affect the individuals' ability for self-regulation Rothbart (1981). 
Most of a child's self- regulatory development is due to the child's increased ability to control attentional processes, as well as motor behaviour (Fox et al., 2001; Kochanska, Coy \& Murry, 2001; Rumemff \& Rothbart, 1996). A key concept in Rothbart's and Ruff's theory (1996) is the idea of effortful control, a group of self-regulatory behaviours that develops with the maturation of attentional abilities. Effortful control begins to emerge at the end of the first year of life, its development continues, at least through preschool years. During the years self-regulatory behaviour becomes more voluntary and systematic which enables the child to fit into society.

The effects of regulatory processes on development processes have become a popular subject for res earch. One theoretical perspective looks to the child-caregiver relationship as the primary context in which children learn to relegate their emotions: research relating to face-to-face interactions between mothers and infants focused on the mutual regulation within the dyad as an important factor in the infants' emotional development (Gianino \& Tronick, 1988; Tronick, 1989).

Deficits in self-regulatory skills underlie or contribute to a range of adverse developmental problems and disorders, including ADHD (Barkley, 1997), eating disorders (Attie \& Brooks-Gunn, 1995) and risk-taking behaviour (Cantor \& Sanderson 1998; Eisenberg et al., 2005). Self-regulation has been recognised as an important factor in aiding academic achievements of school-age children, less has been written about the subject in early childhood, yet the development of self-regulation has been described as an important milestone in early childhood (Shonkoff \& Phillips, 2000).

The executive functions of the brain play a significant role in self-regulatory behaviours including 'effortful control', meaning the ability to manage attention or activate adaptive behaviour. Longitudinal research shows that the extended attention ability in a nine- month-old child is indicative of increased ability to show effortful control behaviour at the age of 22 months (Kochanska, Murray \& Harlan, 2000). Furthermore, parents' reports concerning kindergarten children that managed to wait patiently to receive reinforcement indicated a higher level of attention, concentration and self-control over negative emotions at adolescence (Mischel, Shoda \& Rodriguez, 1989). Ability to engage in self-regulating behaviour is connected to levels of effortful control and involve attention executive abilities (Bronson, 2000).

The ability to apply self-control is also an important element in social acceptance. During this time, children shift from primarily external control to internal control, but the environment still plays a critical role in the development of selfregulation. It provides opportunities to develop new strategies and to practice increasing self-regulatory control. It also provides constraints within which children must operate. They begin to build in ternalised standards of behaviour that they can use as a guide in the absence of adults. They can talk about mental states, such as thinking and believing and develop a more sophisticated understanding of other minds (Bronson, 2000).

Preschool and kindergarten children are more advanced than infants in their ability to achieve cognitive selfregulation. They can select goals that are suitable for their age group and work consistently to reach these goals. In a widening range of tasks, they can resist distraction, use appropriate and effective strategies to monitor their progress and reach their goals successfully. Adults in their environments, specifically caregivers or kindergarten teachers that offer suitable language strategies, assist in the development of cognitive self-regulation. Questions that help children generate their solutions foster the development of independent problem- solving skills (Casey \& Lippman, 1991; Casey \& Tucker, 1994). During this period, children also become interested in the products that they produce and begin to evaluate their products according to internal or external standards. Children have motivation for selfregulation when they believe that that they are responsible for their actions, that they are capable of controlling them and that they have choices (Bronson, 2000).

\section{Supporting the Development of Self- Regulating Behaviours}

Responsive and close interactions that respect the child's growing autonomy and sense of self, support growth in selfdirection (Nucci et al., 1996). The child is more willing to adapt and internalise adult behaviour and when the relationship is loving and trusting (Sroufe, 1996). Coercive external control may result in immediate compliance, but it undermines the development of internal self-regulation (Lepper, 1983). Strategies that allow the child to gain control over their behaviour offer limited appropriate options, use suggestions rather than commands and focus on 
explanations rather than direct orders since these strategies are most likely to lead to inner control (Hoffman, 1970b; Maccoby, 1980). By providing opportunities to make decisions and choices and attributing inner control to the child, these strategies support self-regulation, since they increase the child's awareness of the decision-making process, and the results of their behaviour. On the other hand, caregiver interaction styles that overwhelm or belittle, or are erratic or unpredictable, make the child feel confused, angry or helpless and undermine the development of in ner control in social situations. The environment mediates the growing understanding of acceptable behaviour.

Children build cognitive self-regulation through the construction of 'schemes' that develop through interaction with the environment, enabling the child to bring coherence to their experience. However, there are individual differences in the child's ability to cope with various levels of stimulation and complexity, so that caregivers need to adjust the environment to suit the needs of individuals in their care.

In addition to empathetic caregiving and showing concern for others, which provide a nurturing environment for pro social behaviour, it is also necessary to verbalize the rules of behaviour and the results that behaviour can have on others (Zhan-Waxler \& Radke-Yarrow, 1982; Zhan-Waxler et al., 1979). Order and predictability in the environment contribute to the development of the ability to focus attention effectively and the ability to engage in self-exploratory playwhile learning how to master activities. Such order also allows children to feel competent and exercise more control, especially when they know where to find things, what comes next and how to participate. In a disorganised or unpredictable environment, they find it difficult to cope effectively. Supporting children's lengthening periods of focused attention in independent activities supports their growing self-direction and persistence.

In contrast to babies, who need substantial support and guidance from adults to help them maintain control, preschool and kindergarten children are increasingly more capable of exercising self-control. As the executive, inhibitory and working memory functions develop, they become more capable of refraining from forbidden behaviours, and can hold in mind and carry out increasingly more complicated directions.

By understanding and supporting the processes involved in the development of self-regulation skills, it might be possible for significant adults in young children's lives to have a substantial effect in aiding young children, who exhibit difficulties in developing self-regulatory behaviour. This was the rationale for the present research.

\section{METHODOLOGY}

In this research, the data-collection and analys is were based on both quantitative and qualitative methods. Quality data was the priority and was collected after and in reliance to the quantitative data results.

For the first part of the study the kindergarten teachers were requested to fill in the Achenbach Child Behaviour Checklist (1992) for kindergarten teachers, C-TRF 1.5-5. A widely used international tool translated into Hebrew for this research..

The request from the kindergarten teachers before filling in the checklists was to think of a child in their care who showed problems of self-regulation and to fill in the checklist according to what they encountered in their daily meetings with these children. One of the advantages of using this tool is the use of T-test scores, which give an indication of the cut-off points for normal behaviour. The checklist consists of 100 items of behaviour that the kindergarten teacher is requested to grade between $0-2$ : $0=$ never occurs, $1=$ sometimes occurs, $2=$ very often occurs.

After receiving the checklists from the kindergarten teachers, the researcher was able to build up profiles of the children in the population sample. The profiles ranged from normative to marginal to clinical behaviour, according to the scores the child received in each category of behaviour. 
Table 1. Correlations between C-TRF T-scores and children's age, teacher's professional seniority, children per kindergarten group, hours spent in group per week, length (months) of teacher-child acquaintance $(\mathrm{N}=30)$.

\begin{tabular}{|c|c|c|c|c|c|}
\hline \multicolumn{6}{|c|}{ Syndrome S cales } \\
\hline & Child's age & $\begin{array}{l}\text { Teacher's } \\
\text { seniority }\end{array}$ & $\begin{array}{l}\text { Children in } \\
\text { group }\end{array}$ & $\begin{array}{l}\text { Hours in group } \\
\text { (per week) }\end{array}$ & $\begin{array}{l}\text { Length teacher- } \\
\text { child acquaintance }\end{array}$ \\
\hline Emotionally Reactive & -.07 & -.11 & -.28 & .25 & .01 \\
\hline Anxious/Depressed & .05 & -.04 & -.14 & .11 & .25 \\
\hline Somatic Complaints & -.11 & .29 & -.15 & .07 & .10 \\
\hline Withdrawn & -.01 & -.22 & -.26 & .07 & .12 \\
\hline Attention Problems & .03 & -.14 & -.18 & .02 & -.04 \\
\hline Aggressive Behaviour & -.16 & -.04 & -.29 & .12 & $-.34^{1}$ \\
\hline Total Internalizing problems & .01 & -.08 & -.27 & .15 & .23 \\
\hline Total externalizing problems & -.11 & -.18 & $-.31^{1}$ & .28 & $-.30^{1}$ \\
\hline Total behaviour problems & -.10 & -.24 & $-.56 * * *$ & $.35^{1}$ & -.10 \\
\hline \multicolumn{6}{|l|}{ DSM-Oriented Scales } \\
\hline Affective Problems & -.06 & -.19 & $-.38^{1}$ & .21 & .10 \\
\hline Anxiety Problems & -.01 & .01 & -.24 & .20 & .06 \\
\hline $\begin{array}{l}\text { Pervasive Developmental } \\
\text { Problems }\end{array}$ & -.08 & -.17 & $-.34^{1}$ & .15 & .12 \\
\hline $\begin{array}{l}\text { Attention Deficit/Hy peractivity } \\
\text { Problems }\end{array}$ & -.04 & -.14 & -.16 & .21 & -.22 \\
\hline Oppositional Defiant Problems & -.11 & -.16 & -.17 & .25 & $-.33^{1}$ \\
\hline
\end{tabular}
${ }^{1} \mathrm{p}<.10, * \mathrm{p}<.05, * * \mathrm{p}<.01, * * * \mathrm{p}<.001$

As can be seen from Tablelabove, one significant correlation was found and a few marginally significant correlations.

- A significant negative correlation was found between the number of children per kindergarten group and the teacher's evaluation of total behaviour problems: larger groups were as sociated with an evaluation of fewer behaviour problems.

Several marginally significant negative correlations were found as follows:

- Three marginally significant negative correlations were found between the number of children per kindergarten group and the teacher's evaluation of total externalizing problems, affective problems, and pervasive developmental problems; larger groups were as sociated with an evaluation of fewer problems.

Three marginally significant negative correlations were found between the length of teacher-child acquaintance and the teacher's evaluation of aggressive behaviour, total externalizing problems, and oppositional defiant problems; longer teacher-child acquaintance was as sociated with an evaluation of fewer problems

From the population sample, three children were selected to take part in an intervention program, which focused on the development of self- regulating behaviour. In addition, to the checklists, post and pre-intervention open-ended interviews were held with the kindergarten teachers.

\section{Intervention Program}

The intervention program was based on teaching strategies of Mediated Learning (Feuerstein, 1991) and scaffolding (Vygotsky,1978) in everyday situations. The program took place in the kindergartens under the auspices of the kindergarten teacher. The researcher and kindergarten teacher meet regularly, once every three weeks, for 3 months for an evaluation. 
The intervention model involved five stages:

1. Identifying and defining a concern,

2. Establishing mutual goals between the kindergarten teachers and the consultant (the researcher) that participated in the program.

3. Co-constructing a pedagogical plan based on scaffolding and mediated learning that could be implemented in the kindergarten.

4. Implementation of the plan in the kindergarten.

5. Collecting data to determine goal achievement.

Figure 1. Illustrates the integration of all the parts of the intervention program to enable the child to achieve self-regulatory behaviours. The organization of the educational environment, the teaching strategies, mediated learning and scaffolding and the supporting of interpersonal relationships.

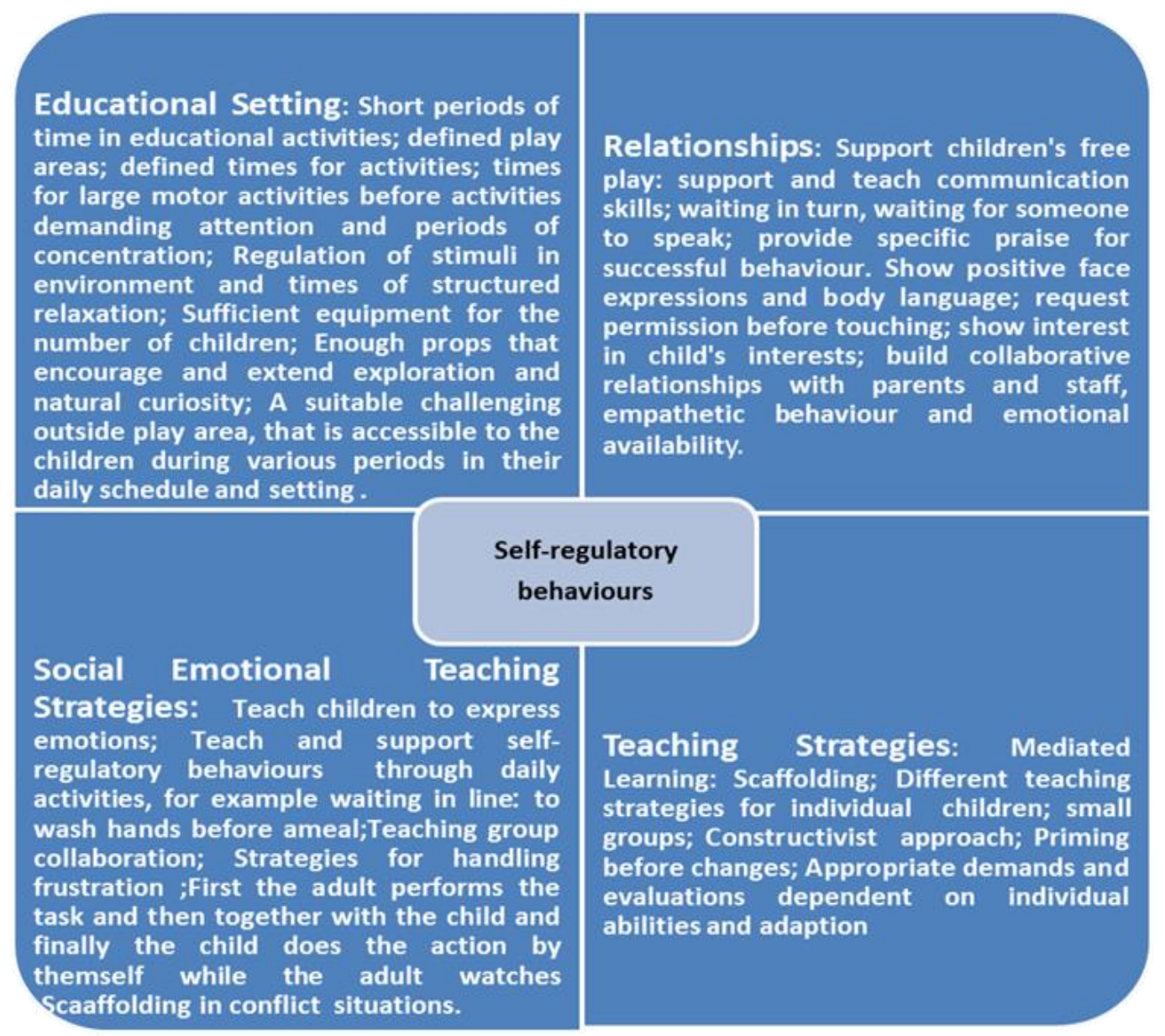


Table 2. Teachers' clinical ranges by child's gender

\begin{tabular}{|c|c|c|c|c|c|c|}
\hline & \multicolumn{3}{|c|}{$\begin{array}{c}\text { Boys } \\
(n=23)\end{array}$} & \multicolumn{3}{|c|}{$\begin{array}{l}\text { Girls } \\
(n=7)\end{array}$} \\
\hline & $\begin{array}{c}\text { normal } \\
\mathbf{N} \\
(\%)\end{array}$ & $\begin{array}{c}\text { marginal } \\
\mathbf{N} \\
(\%)\end{array}$ & $\begin{array}{c}\text { clinical } \\
\mathbf{N} \\
(\%)\end{array}$ & $\begin{array}{c}\text { normal } \\
\mathbf{N} \\
(\%)\end{array}$ & $\begin{array}{c}\text { marginal } \\
\mathbf{N} \\
(\%)\end{array}$ & $\begin{array}{c}\text { clinical } \\
\mathbf{N} \\
(\%)\end{array}$ \\
\hline \multicolumn{7}{|l|}{ Syndrome Scales } \\
\hline Emotionally Reactive & $\begin{array}{c}11 \\
(47.8)\end{array}$ & $\begin{array}{c}4 \\
(17.4)\end{array}$ & $\begin{array}{c}8 \\
(34.8)\end{array}$ & $\begin{array}{c}5 \\
(71.4)\end{array}$ & $\begin{array}{c}1 \\
(14.3)\end{array}$ & $\begin{array}{c}1 \\
(14.3)\end{array}$ \\
\hline Anxious/ Depressed & $\begin{array}{c}12 \\
(52.2)\end{array}$ & $\begin{array}{c}4 \\
(17.4)\end{array}$ & $\begin{array}{c}7 \\
(30.4)\end{array}$ & $\begin{array}{c}7 \\
(100.0)\end{array}$ & 0 & 0 \\
\hline Somatic Complaints & $\begin{array}{c}16 \\
(69.6)\end{array}$ & $\begin{array}{c}3 \\
(13.0)\end{array}$ & $\begin{array}{c}4 \\
(17.4)\end{array}$ & $\begin{array}{c}6 \\
(85.7)\end{array}$ & 0 & $\begin{array}{c}1 \\
(14.3)\end{array}$ \\
\hline Withdrawn & $\begin{array}{c}16 \\
(69.6)\end{array}$ & $\begin{array}{c}5 \\
(21.7)\end{array}$ & $\begin{array}{c}2 \\
(8.7)\end{array}$ & $\begin{array}{c}6 \\
(85.7) \\
\end{array}$ & 0 & $\begin{array}{c}1 \\
(14.3)\end{array}$ \\
\hline $\begin{array}{l}\text { Attention } \\
\text { Problems }\end{array}$ & $\begin{array}{c}14 \\
(60.9)\end{array}$ & $\begin{array}{c}3 \\
(13.0)\end{array}$ & $\begin{array}{c}6 \\
(26.1)\end{array}$ & $\begin{array}{c}4 \\
(57.1)\end{array}$ & 0 & $\begin{array}{c}3 \\
(42.9)\end{array}$ \\
\hline Aggressive Behavior & $\begin{array}{c}8 \\
(34.8)\end{array}$ & $\begin{array}{c}10 \\
(43.5)\end{array}$ & $\begin{array}{c}5 \\
(21.7)\end{array}$ & $\begin{array}{c}3 \\
(42.9)\end{array}$ & $\begin{array}{c}4 \\
(57.1)\end{array}$ & 0 \\
\hline $\begin{array}{l}\text { Total Internalizing } \\
\text { problems }\end{array}$ & $\begin{array}{c}8 \\
(34.8)\end{array}$ & $\begin{array}{c}5 \\
(21.7)\end{array}$ & $\begin{array}{c}10 \\
(43.5)\end{array}$ & $\begin{array}{c}4 \\
(57.1)\end{array}$ & $\begin{array}{c}2 \\
(28.6)\end{array}$ & $\begin{array}{c}1 \\
(14.3)\end{array}$ \\
\hline $\begin{array}{l}\text { Total externalizing } \\
\text { problems }\end{array}$ & $\begin{array}{c}5 \\
(21.7)\end{array}$ & $\begin{array}{c}3 \\
(13.0)\end{array}$ & $\begin{array}{c}15 \\
(65.2)\end{array}$ & $\begin{array}{c}1 \\
(14.3)\end{array}$ & 0 & $\begin{array}{c}6 \\
(85.7)\end{array}$ \\
\hline Total behavior problems & $\begin{array}{c}1 \\
(4.3) \\
\end{array}$ & $\begin{array}{c}6 \\
(26.1) \\
\end{array}$ & $\begin{array}{c}16 \\
(69.6) \\
\end{array}$ & $\begin{array}{c}1 \\
(14.3) \\
\end{array}$ & $\begin{array}{c}2 \\
(28.6) \\
\end{array}$ & $\begin{array}{c}4 \\
(57.1) \\
\end{array}$ \\
\hline \multicolumn{7}{|l|}{ DSM-Oriented Scales } \\
\hline Affective Problems & $\begin{array}{c}17 \\
(73.9)\end{array}$ & $\begin{array}{c}4 \\
(17.4)\end{array}$ & $\begin{array}{c}2 \\
(8.7)\end{array}$ & $\begin{array}{c}6 \\
(85.7)\end{array}$ & 0 & $\begin{array}{c}1 \\
(14.3)\end{array}$ \\
\hline Anxiety Problems & $\begin{array}{c}18 \\
(78.3)\end{array}$ & 0 & $\begin{array}{c}5 \\
(21.7)\end{array}$ & $\begin{array}{c}7 \\
(100.0)\end{array}$ & 0 & 0 \\
\hline $\begin{array}{l}\text { Pervasive Developmental } \\
\text { Problems }\end{array}$ & $\begin{array}{c}14 \\
(60.9)\end{array}$ & $\begin{array}{c}2 \\
(8.7)\end{array}$ & $\begin{array}{c}7 \\
(30.4)\end{array}$ & $\begin{array}{c}5 \\
(71.4)\end{array}$ & $\begin{array}{c}1 \\
(14.3)\end{array}$ & $\begin{array}{c}1 \\
(14.3)\end{array}$ \\
\hline $\begin{array}{l}\text { Attention Deficit/ } \\
\text { Hyperactivity Problems }\end{array}$ & $\begin{array}{c}10 \\
(43.5)\end{array}$ & $\begin{array}{c}9 \\
(39.1)\end{array}$ & $\begin{array}{c}4 \\
(17.4)\end{array}$ & $\begin{array}{c}5 \\
(71.4)\end{array}$ & $\begin{array}{c}1 \\
(14.3)\end{array}$ & $\begin{array}{c}1 \\
(14.3)\end{array}$ \\
\hline $\begin{array}{l}\text { Oppositional Defiant } \\
\text { Problems }\end{array}$ & $\begin{array}{c}16 \\
(69.6) \\
\end{array}$ & $\begin{array}{c}6 \\
(26.1) \\
\end{array}$ & $\begin{array}{c}1 \\
(4.3)\end{array}$ & $\begin{array}{c}6 \\
(85.7)\end{array}$ & 0 & $\begin{array}{c}1 \\
(14.3)\end{array}$ \\
\hline
\end{tabular}

Note. It is not possible to calculate gender differences due to small cell sizes. It is necessary to take caution in the interpretation of percents, due to small cell sizes

\section{RESULTS}

\section{Results from Table 2}

Table 2 shows the distribution of the ranges of behavior in the syndrome scales and DSM-Orientated scales. The ranges are between normative, marginal and clinical.

The number of boys identified with difficult behaviours was larger than the number of girls: 23:7.

From the table. it is possible to discern that the distribution of the ranges of behavior extends between all levels, normative, borderline and clinical. In the boys'sample in the syndrome scales, there were 8 in the clinical range for emotionally reactive and 4 in the marginal range:12 altogether $(52 / 2 \%)$ who are at risk.

Also, 6 were in the clinical range for attention problems, $(26.1 \%)$ and $3(13.0 \%)$ in the border range, all together $39.1 \%$ The largest number of boys in the clinical range was in the category of total behavior problems, $16(69.9 \%)$ of the sample population.

There were indications of aggressive behavior, $10(43.5 \%)$ in the marginal range and $5(21.7 \%)$ in the clinical range, all together $65.2 \%$. 
In the DSM-Orientated scales, there were $4(17.4 \%)$ in the clinical range and $9(39.1 \%)$ in the marginal range for attention hyperactivity problems. Identification of lack of concentration and impulsive behavior are related to Attention Hyperactive behaviour (Barkley, 1997). Altogether $56.5 \%$ of the population sample who are at risk.

There were 7:30.4\% with Pervasive Developmental problems in the clinical range and 2: 8.7\% in the marginal range.

It is necessary to remember that these children came from mainstream kindergartens. According to the research there are a number of children with clinical and borderline profiles, visiting these kindergartens every day.

In the girls' sample, the distribution was slightly different.

For attention problems, 3 were in the clinical range and 4 in the normative range, 0 in the marginal range.

The highest number in the girl population in the clinical range was found in the Total externalizing problems, 6 $(85.7 \%)$, and only 1 in the normative range.

In the aggressive behavior category, there were no girls in the clinical range,4 in the marginal $\operatorname{range}(57.1 \%)$.

These scales show the wide range of behavior between normative to clinical for both boys and girls. The research looked at the characteristics of a lack of self-regulating behaviours. These were identified in both girls and boys.

\section{Results from Open-Ended Interviews with Kindergarten Teachers Before and After Intervention}

Table 3. Behavioural traits identified in the pre-intervention interviews by the kindergarten teachers, by category

\begin{tabular}{|c|c|c|}
\hline Impulsivity & Difficulties in self-regulation & Feelings \\
\hline $\begin{array}{ll}\text { - } & \text { Impulsive } \\
\text { - } & \text { Dangers herself } \\
\text { - } & \text { Unpredictable }\end{array}$ & $\begin{array}{l}\text { - Lack of control } \\
\text { - Difficulty in self-relaxation } \\
\text { - Cannot stop when asked to } \\
\text { - Difficulties in delay ing self-gratification } \\
\text { - Internal agitation } \\
\text { - Needs outside help to help her interact } \\
\text { - With the children } \\
\text { - Aggressive behaviour } \\
\text { - Unruly behaviour } \\
\text { - Runs away } \\
\text { - Messy in eating } \\
\text { - Talks a lot } \\
\text { - Climbs on every thing } \\
\text { - Difficulty in falling asleep } \\
\text { - Throws chairs } \\
\text { - Cries extensively } \\
\text { - Difficulties in changes } \\
\text { - He is alway s checking the boundaries, what } \\
\text { - "Se can do, what is dangerous } \\
\text { "Theaks with a very loud voice all the time," } \\
\text { - "Talks all the time", "Cannot stop when } \\
\text { - "Uinds it difficult to internalize the rules and } \\
\text { problems" }\end{array}$ & $\begin{array}{ll} & \text { Frustrated } \\
- & \text { Anger } \\
\text { - } & \text { Difficult days } \\
\text { - } & \text { There are days when it feels like the } \\
\text { "war of attrition } \\
\text { - There are days when I cannot wait } \\
\text { until 16.00(the end of the day). } \\
\text { - It is still very difficult despite all we } \\
\text { do }\end{array}$ \\
\hline
\end{tabular}


Table 4. Behavioural traits identified in the post-intervention interviews with the kindergarten teachers, by category

\begin{tabular}{|c|c|c|}
\hline Less Impulsivity & Self-regulation & Feelings \\
\hline $\begin{array}{l}\text { Thinks before he does } \\
\text { things } \\
\text { - He can build without } \\
\text { destroy ing the building: } \\
\text { once he would build - } \\
\text { destroy - build- destroy } \\
\text { now he builds } \\
\text { - Manages to stop himself } \\
\text { - Can regulate himself when } \\
\text { frustrated, cries a lot less } \\
\text { - Can sit longer in circle time }\end{array}$ & $\begin{array}{l}\text { - } \text { Does less dangerous things } \\
\text { - } \text { Manages to stop himself } \\
\text { - She internalizes what is expected of her } \\
\text { - } \text { Doesn't run away } \\
\text { - } \text { Better able to state what she needs without crying } \\
\text { - Plays better } \\
\text { - Advancement in little things but significant things } \\
\text { - Can regulate himself at times of frustration, cries a } \\
\text { - } \text { lot less } \\
\text { - Als in a much more regulated way } \\
\text { - Greater improvement in social behaviour, All the } \\
\text { interpersonal interactions have improved: with the } \\
\text { children and the staff, His self-regulation has } \\
\text { entirely improved } \\
\text { - So running or jumping on the trampoline before he } \\
\text { has to sit in circle time helps him be more focused. } \\
\text { And after sitting for a period he needs to be able to } \\
\text { move around. } \\
\text { - Also, he sits next to me, and my touch helps him be } \\
\text { calmer and be more focused } \\
\text { At meal times, allowing him to eat with a tablespoon } \\
\text { cause less room for comments, makes for a more } \\
\text { pleasant meal. . }\end{array}$ & $\begin{array}{l}\text { - } \quad \text { Less frustrated } \\
\text { - } \text { Wonderful to see him } \\
\text { - } \quad \text { She builds so nicely } \\
\text { - } \quad \text { We are better able to be } \\
\text { empathetic to her } \\
\text { - } \quad \text { I see significant results } \\
\text { - } \quad \text { We have a "tool" to work } \\
\text { with } \\
\text { - } \text { I almost cried when I saw him } \\
\text { working nicely } \\
\text { - } \text { Better experience with her } \\
\text { - All child's interpersonal } \\
\text { interactions have improved: } \\
\text { with children and staff } \\
\text { - I feel that I have tools to work } \\
\text { with, you have filled my "box } \\
\text { of tools". } \\
\text { These are all small things but } \\
\text { very important because they } \\
\text { occur every day, a number } \\
\text { times during the day. It is a } \\
\text { real change in the quality of } \\
\text { life in the kindergarten }\end{array}$ \\
\hline
\end{tabular}

\section{CONCLUSIONS}

Self-regulating behaviour is an important skill in modern life. Research shows that a child develops internal selfregulatory behaviour within the context of biological and environmental factors. The motivation for self-regulation occurs when children believe that that they are responsible for their actions, that they are capable of controlling them and that they have choices (Bronson, 2000).

This research implemented an intervention program which aimed to increase the children's self-regulatory behaviours through pedagogical measures. According to the findings, the intervention program was successful in increasing certain aspects of the children's self -regulatory behaviours in the kindergarten settings.

The research showed that in kindergartens there were a proportion of children with challenging behaviours, above normative levels. The kindergarten teachers indicated that they found it difficult to cope with these challenges and that they lacked the appropriate tools and skills to be able to contain these behaviours. Without early diagnosis and professional consultation, the kindergarten teachers are alone in their daily management of these children. This lack of knowledge and skills for efficiently working with these children could lead to a high level of frustration or even feelings of failure when teachers try to advance the group or specific children in the group. Also the interpersonal interactions between the significant adults in the children's life are very often negative for the child, thereby affecting their self-image and confidence.

It is therefore important to find tools for early identification of challenging behaviours, combined with a suitable intervention program targeted to reduce these behaviours. Thereby aiding integration and consequently enhance the emotional climate of the educational setting. The program suggested in this research and was seen to be effective is unique in that it empowers the kindergarten teacher to implement the program and that it is easily applicable to the daily routine of kindergarten. There is no need to take the child out of the educational setting to a clinical situation, once a week. The program is implemented in the child's natural environment every day. 
Integration of children with special needs is part of the educational philosophy of modern education, it is therefore vital that all kindergarten teachers should receive the necessary skills and knowledge for working with children who exhibit difficult behaviours. Not only students that are studying to be kindergarten teachers in special education.

\section{AUTHOR BIOGRAPHY}

Dr. Aviva Dan is Head of Department for Early Childhood Studies in a teachers' training college in the North of Israel. She also acts as a professional consultant for Early Childhood Educational frameworks in local regional council and Kibbutzim in the North of Israel. In addition, she tutors Ph.D. students during their doctoral studies.

\section{REFERENCES}

Achenbach, T. (1992). Manual for the Child Behavior Checklist/2-3 and Profile. Burlington, VT: University of Vermont Department of Psychiatry.

Attie, I., \& Brooks-Gunn, J. (Ed.) (1995). The development of eating regulation across the life span. (Vol. 2.) New York: Wiley, Interscience.

Bandura, A. (1977). Social learning theory. Englewood Cliffs NJ: Prentice Hall.

Bandura, A. (1997). Self-efficiency: The exercise of control. New York: H. Freeman.

Barkley, R.A. (1997). ADHD and the nature of self-control, New York: Guildford Press.

Bronson, M. B. (2000). Self-regulation in early childhood, New York, NJ: Guildford Press.

Brown, A. L. (1978). Knowing when, where and how to remember: A problem in mega cognition. (Vol. 1). New Jersey: Erlbaum.

Brown, A. L., \& DeLoache, J. S. (1978). Skills, plans and self-regulation. In R. S. Siegel Ed. (Children's thinking: What develops? (pp. 3-35). Hillsdale, N.J.: Erlbaum.

Cantor, N., \& Sanderson, C. A. (1998). The functional regulation of adolescent dating relationships and sexual behavior: An interaction of goals, strategies, and situations. In J. Heckhausen \& C. S. Dweck (Eds.), Motivation and self-regulation across the life span (pp. 185-215). Cambridge: Cambridge University Press.

Case, R. (1992). The role of the frontal lobes in the regulation of cognitive behavior. Brain and Cognition, 20, 51-73.

Casey, M.B., \& Lippman, M. (1991). Learning to plan through play. Young Children, 46, 52-58.

Casey, M.B., \& Tucker, E.C. (1994). Lifelong learning in a problem-centred classroom. Phi Delta Kappa, 139-143.

Eisenberg, N. Sadovsky, A., \&. Shepard, S.A. (2005). The relations of problem behavior status to children's negative emotionality, effortful control, and impulsivity: Concurrent relations and prediction of change. Developmental Psy chology 41(1) 193-211.

Erikson (Ed.). (1950). Childhood and society. New York: Norton.

Flavell, J. H. (1978). Mega-cognitive development. In J. M. S. C. Brainerd (Ed.), Structural/process theories of complex human behavior. Alphenan der Rijn, Netherlands: Sitjoff \& Wordhoff.

Flavell, J.H., Miller, R.P.H., \& Miller, S.A. (2002). Cognitive development (4th ed.). Upper Saddle River, NJ: Prentice Hall.

Fox,N.A., Haderson,H.A., Rubin, K.H., Calkins, S.D., \& Schmidt, L.A. (2001). Continuity and discontinuity of behavioral inhibition and exuberance psychobiological behavioral influences across the first four years of life. Child Development, $72,1-21$.

Freud, A. (1936), The ego and the mechanisms of defense. In M. B. Bronson (Ed.), Self-regulation in early childhood. New York: Guildford Press.

Feuerstein, R., \& Feuerstein, S. (1991). Mediated learning experience: A theoretical review. In R. Feuerstein, P .Klein, \& A. Tannenbaum (Eds.) Mediated learning experience (MLE): Psychosocial and learning implications. (pp. 3-51). London: Freund Publishing House

Gianino, A., \& Tronick, E. Z. (1988). The mutual regulation model: The infants' self and interactive regulation coping and defense. In T.Field, P. McCabe, \& N. Schneiderman (Eds.), Stress and coping. (pp. 47-68). Hillsdale, NJ: Erlbaum.

Hoffman, M.L.(1970b). Conscience, personality and socialization techniques. Human Development, 1, 90-126.

Johnson, M.I., \& Rothbart M.K. (1991). Components of visual orienting in early infancy: Contingency learning, and anticipatory looking and disengaging Journal of Cognitive Neuroscience, 3, 335- 344.

Klein, P., \& Yablon, B. (2008). From research to practice in early childhood education. Convened by the Initiative of Research for Educational Practice, The Israel Academy of Sciences and Humanities, The Ministry of Education and Yad HaNadiv [Hebrew].

Kochanska G, M. K., \& Harlan et al., (2000). Effortful control in early childhood: Continuity and change, antecedents and implications for social development. Developmental Psychology, 36(2), 220-232.

Kochanska, G., Coy, K.C., \& Murry, K.T. (2001). The development of self-regulation in the first four years of life. Child Development, 72, 1091-1111.

Kopp, C. (1982). Antecedents of self-regulation: A developmental perspective. Developmental Psychology, 18, $199-214$. Kopp, C. (Ed.) (1991). Young children's progression to self-regulation. Basel: Karger. 
Lepper, M.R. (1983). Social-control processes and the internalization of social values: An attributional perspective. In E.T. Higgins, D.N. Rible, \& W.W. Hartup (Eds.), Social cognition and social development: A sociocultural perspective. Cambridge, UK: Cambridge Press.

Lewis, M., Alessandri, S., \& Sullivan, M.W. (1992). Differences in shame and pride as a function of children's gender and task difficulty. Child Development, 6, 630-638.

Maccoby, E.E. (1980). Social development: Psychological growth and the parent-child relationship. San Diego: Harcourt, Brace, Jovanovich.

Mischel, W., Shoda, Y., \& Rodriguez, M.L., (1989). Delay of gratification in children, Science, 244, 933-938.

Nucci, L.P., Kille, M., \& Smetana, J.G. (1996). Autonomy and the personal: Negotiation and social reciprocity in adult-child social exchanges. In M.Killen (Ed), New directions for child development. No.73: Children's autonomy, social competence and interactions with adults and other children: Exploring connections and consequences. San Francisco: Jossey-Bass.

Piaget, J. (1985). The equilibration of cognitive structures: The central problem of intellectual development. Chicago: University of Chicago Press.

Posner, M.., \& Rothbart, M.K. (2000). Developing mechanisms of self-regulation. Development \& Psychopathology, 12, 427441.

Rothbart, M.K., \& Jones, L.B. (1998). Temperament, self-regulation, and education. School Psychology Review. 27(4) $479-491$.

Rothbart, M.K. (1981). Measurement of temperament in infancy. Child Development 52, 569-578.

Rothbart, M. K., Derry berry, D., \& Hershey, K. (2000). Stability of temperament in childhood: Laboratory infant assessment to parent report at seven years. In V. J. Molfese \& D. L. Molfese (Eds.), Temperament and personality development over the life span (pp. 85-119). Hillsdale, NJ: Erlbaum.

Ruff, H.A., \& Rothbart, M.K. (1996). Attention in early development: Themes and variations. London: Oxford University Press. Shonkoff, J.P., \& Philips D.A. (Eds.) (2000). From neurons to neighborhoods: The science of early childhood development. Washington, DC: National Academy Press.

Skinner, B. F. (Ed.). (1938). The behavior of organisms: An experimental analysis. Englewood Cliffs N.J: Prentice Hall.

Sroufe, L.A. (1996). Emotional development: The organization of emotional life in the early years. New York: Cambridge University Press.

Sroufe, L. A. (1997). Psychopathology as an outcome of development. Development and Psychopathology, 9, 251-268

Thomas, A., Chess, S., \& Birch, H.G. (1968).Temperament and behavior disorders in children. New York: New York University Press.

Tronick, E.Z. (1989). Emotions and emotional communication in infants. American Psychologist, 44, 112-119.

Vygotsky, L.S. (1962), Thought and Language. Cambridge MA: MIT Press.

Vygotsky, L. S. (1978). Mind in society: The development of higher psychological processes. M. Cole, V. John -Steiner, S. Scribner, \& E. Souberman (Eds.) Cambridge, MA: Harvard University Press.

Vygotsky, L. S. (Ed.). (1986). Thought and language. Cambridge MA: MIT Press.

Zahn-Waxler, C., Radke-Yarrow, M., \& King, R.A. (1979). Child rearing and children's prosocial initiations toward victims of distress. Child Development, 50, 319-330.

Zahn-Waxler, C., \& Radke-Yarrow, M. (1982). The development of altruism: Alternative strategies. In N. Eisenberg (Ed.), The development of prosocial behavior. New York: Academic Press. 